\title{
Kgarebe (virgin) and carnal knowledge: Reading Genesis 19:30-38 from the margins
}

\begin{abstract}
Author:
Madipoane Masenya

(Ngwan'a Mphahlele) $)^{1}$ (D)

Affiliation:

${ }^{1}$ Department of Biblical and Ancient Studies, College of Human Sciences, University of South Africa, Pretoria,

South Africa

Corresponding author: Madipoane Masenya, masenmj@unisa.ac.za

Dates:

Received: 01 June 2020 Accepted: 09 Oct. 2020 Published: 27 Jan. 2021

How to cite this article: Masenya (Ngwan'a Mphahlele), M., 2021, 'Kgarebe (virgin) and carnal knowledge: Reading Genesis 19:30-38 from the margins', HTS Teologiese Studies/Theological Studies 77(3), a6178. https://doi. org/10.4102/hts.v77i3.6178

\section{Copyright:}

(c) 2021. The Authors. Licensee: AOSIS. This work is licensed under the Creative Commons Attribution License.
\end{abstract}

\section{Read online:}

Scan this QR
code with your
smart phone or
mobile device
to read online.

In this article, issues of carnal knowledge, gender (read: daughters) and agency as evident in selected texts from the Judeo-Christian tradition and the African context in South Africa are interrogated. Do the ideologies embedded in religious texts endorse unequal power relations between male and female human beings (batho)? Of particular interest for the present investigation is the issue of carnal knowledge as it is understood in African (Northern Sotho) contexts and the Hebrew Bible (cf. Gn 19) context. Informed by the insights from both the African and the ancient Israelite contexts, the key questions that this essay seeks to engage are: when the notion of carnal knowledge is engaged with, in the context of daughters in both African and biblical contexts, which insights may emerge? Can such insights contribute to the affirmation of daughters as persons with agency?

Contribution: Dealing with a scarcely researched upon topic within the circles of South African Old Testament scholarship, that is, the OT text (Genesis) (sex)uality and the agency of younger women (read: daughters), through the knowledge produced herein, the HTS will be enabled to make a needed impact in patriarchal African and global contexts .

Keywords: carnal knowledge; kgarebe (virgin); agency; patriarchy; Genesis 19:30-38; Lot's daughters; humanity; Black Liberation Theology.

\section{Introduction}

VukaniBantuTsohangBatho is the brainchild of the Honoree, the late Professor Vuyani Vellem. Vellem's aim in establishing VukaniBantuTsohangBatho was to make an investment in spiritual capital for the liberation of humanity (batho), in general, and Black African people, in particular. Embedded in the preceding name is not only the sense of urgency in which things have to be done and projects to be completed but also an expectation of a commitment to agency. What quickly comes to mind here, also in light of the topic under investigation, are the following Northern Sotho proverbs: sešo se baba mongwai wa sona [a sore itches to its owner] and ngwana yo a sa llego o hwela tharing [a child who does not cry dies strapped at the back of his or her mother]. The tenor of the first proverb tends to problematise the communal mentality of African people in that it elevates or rather celebrates an individual human being. The individual self seems to be given centre stage. The proverb seems to warn us that each human being, irrespective of his or her gender, race, class, age and geography amongst others, has full human dignity first, as an individual motho [human being] before he or she becomes part of a collective. Patriarchal history though, has taught female human beings that their individuality is almost always part of a collective with its legitimation of patriarchy.

Why is the focus on the individual? It is only that person who has a sore, who will feel its itchiness. Nobody else will thus scratch the itchy part of the body on behalf of the sore's owner. He or she has to do it himself or herself. The history of the Black Theology of Liberation in our South African context has clearly revealed that those who were not bothered by the sore of patriarchy, possibly because they were the perpetrators of the same in Black African contexts, could indeed not be bothered or cared less about the itchiness of the sore (read: patriarchy and the subordination of Black female humanity). The sores that appeared to have bothered former Black liberation theologians were rather those of racism and classism. Mofokeng (1986) could thus argue that the arrival of armed colonial Europeans in South Africa determined how our ancestors responded to the preceding incursion:

Their act of forcing a foreign, capitalist economic system upon our forefathers as well as relegating them to a position of cheap labourers determined the nature of the social, political and economic history of South Africa. (p. 113)

Note: Special Collection entitled VukaniBantuTsohangBatho - Spirituality of Black Liberation, sub-edited by Fundiswa Kobo (UNISA) and Rothney Tshaka (UNISA). 
It is no wonder that the theory and praxis of Bible and Theology in South Africa basically point in the preceding direction as they (with a few exceptions (cf. Mosala 1988)), basically engaged race issues. However, their Black sisters have experienced also the sore of sexism, even before the arrival of the White people in the country. Ramodibe (1989) could thus reason:

African tradition and culture present themselves to women as an oppressive system. It has a male domineering factor. It is a patriarchal system. This oppressive patriarchal system was found in South Africa even before Whites came with their Western capitalistic culture. Capitalistic culture had reinforced the oppressive system, out of which it derives more benefits. (pp. 14-21)

Black women in South Africa, as I will hint in the bosadi concept here below, thus know the sore caused by the multiple oppressive forces of racism, sexism and classism, amongst others (cf. Masenya [ngwana' Mphahlele] 2004:57-64; William 1990:24). However, African women's conditions were not taken seriously by African intellectuals. Oduyoye (1994) rightfully reasons:

Just as Christian theologians (mostly Western and mostly male) never took seriously the situation of oppressed people when formulating their ideas, so African male intellectuals, including theologians, have not given much attention to women in their various enterprises. (p. 192)

Hence, Mosala (1986:129-133) argued that liberation does not fall onto one's lap; it has to be claimed.

Whilst the first proverb focuses on the self and its possession of a sense of agency, the second one includes both the self and the caring Other, the one who would after hearing the cry of the baby attend to him or her accordingly: feed him or her and attend to his or her pampers, amongst others. As batho, whether male or female or differently sexually-orientated, we cannot afford to watch a crying baby and do nothing about the cry. Informed by the preceding name, VukaniBantuTsohangBatho, and the wisdom entailed in the preceding African proverbs, and also motivated by the urgency and agency through which Vellem understood the need for the transformation of our contexts, even in my commitment to challenge patriarchy both in the biblical texts and in our varying Black South African contexts, this article will focus on the following two questions: When the notion of carnal knowledge is engaged with, in the context of daughters in both African and biblical contexts, which insights may emerge? Can such insights contribute to the affirmation of daughters as persons with the agency?

As a point of departure, firstly, I will introduce the approach that will be used to engage the subject matter investigated in this study. Secondly, I will engage the theme, kgarebe, a subject of (carnal) knowledge. Thirdly, I will discuss the theme on daughters, agency and (carnal) knowledge in
Genesis 19:30-38. The fourth section will constitute the conclusion to the essay.

A brief word about the approach is now in order.

\section{Research methodology}

Having been steeped in Eurocentric ways of knowing and theorising early in my Biblical Studies training, my late conscientisation that the Bible and Theology offerings were basically androcentric in perspective and orientation and cognisant that a sore itches to its owner, in a previous research, I developed a bosadi approach to the reading of biblical texts. As an African-conscious approach, it may assist us in unpacking the contents of the present essay.

My predecessors in the Black Liberation Theology (BLT) School, the ones on whose steps Vellem would later follow, had taught me that the Bible could be used to address the harsh realities, which affect the marginalised Black masses on the ground. ${ }^{1}$ The author is reticent that the writings of Black liberation theologians enabled her to be able to engage the Bible basically as a Black person (read: Black man). Her femaleness was on the whole not given the needed attention by the proponents of the BLT. The works of very few Black women included in the volume by Ackermann, Draper and Mashinini (eds. 1992) and Mosala and Tlhagale (1986) came in handy in terms of addressing the multiple dimensions of the experiences of Black women in the theory and praxis of Bible and Theology.

The Northern Sotho word for woman is mosadi. ${ }^{2}$ The preceding word is also found in other South African indigenous languages. The following examples can be cited: wansati [Xitsonga]; umfazi [isiZulu]; musadzi [Tshivenda]; mosadi [Setswana and Sesotho] (see Masenya [ngwana' Mphahlele] [2004:122]). In fact, the root -(s)adi does occur in other African languages outside of South Africa (cf mwasi in the Mongo of DRC; -mkazi in Chewa (Malawi) and sadi in the Setswana of Botswana, amongst others). The bosadi approach will thus probably enable the author to read the Bible informed by the multiple experiences of African-South African women. The major hermeneutical focus of the bosadi biblical hermeneutic is the unique experiences of an AfricanSouth African woman with an emancipatory commitment. Facing varied life-denying forces like sexism in the broader post-apartheid South African society, sexism in the African culture, post-apartheid racism, classism, HIV and AIDS, COVID-19 and ecological degradation amongst others, African women are made the main hermeneutical foci in scholars' interaction with biblical texts.

1.For a more detailed analysis on the three strands of BLT, that is, (see The three strands of the School, that is Black Solidarity Strand, Non-Racialist Strand and the Black Solidarity Materialist Strand, see Kobo (2019).

2.The generic Northern Sotho word mosadi (cf Hebrew îššăh) can be used to designate a woman irrespective of her marital status. Thus, although the preceding observation is noteworthy, traditionally and even today, to some extent, the word mosadi seems to be a fitting designation for a married woman, a mohumagadi, a word translated as wife in English. As can be speculated, heterosexual marriages appear to be the norm in many African and global culture. 
The present essay will, however, not be based on the story of women (basadi) in the biblical text, but on the narrative about daughters. The preceding category of people, even more than women, have been marginalised not only by biblical narrators but also by the history of Bible interpretation through the years. The book recently written by Russaw (2018), an African-American Hebrew Bible scholar, Daughters in the Hebrew Bible, thus comes in handy. Because of the fact that a daughter is a female human being and a mosadi-in-the making, the bosadi reading of the text of Genesis 19:30-38 should enable us to come up with a reading that may deconstruct problematic ideologies about what normative femininity (and masculinity) is, or should be, in both our African contexts and contexts of the production of biblical texts.

The key questions that this essay seeks to engage are: When the notion of carnal knowledge is engaged in the context of daughters in both African and biblical contexts, which insights may emerge? Can such insights contribute to the affirmation of daughters as persons with agency?

\section{Kgarebe, a subject of (carnal) knowledge?}

When the Northern Sotho word, kgarebe [a virgin] is used in the context of carnal knowledge, an underlying female agency almost always exists. How so? There is an expression, kgarebe yeo e sa tsebego monna (translated as, 'a virgin who has not known a man'). A man does not know a virgin; it is a virgin who is the subject of the knowledge of a male body according to the preceding expression.

In my search for answers to the theme under investigation, I posed the following question to an academic in the Department of African languages at one of the South African universities: 'What is the Northern Sotho word for the English word "virgin?"' In her attempt to get an answer to what at face value may have appeared to be a simple and straightforward question, Professor ML Mojapelo (pers. conv., 04 February 2020) posed the same question to three men. As the men grappled with the answer from the point of view of the English language and the Christian Bible, Mojapelo was resolute in expecting a purely African (Northern Sotho) word. The following phrase seemed to carry what could be regarded as a more appropriate answer to an apparently simple, yet illusive question: kgarebe yeo e sa tsebego monna (literally, a grown-up girl who does not know a man). In the preceding context, kgarebe, who is always a daughter in her father's patriarchal household, is described in terms of an anticipated connection to, or a relationship with a man in a heterosexual marriage context. The preceding description, it may be argued, not only denies the full human dignity of female human beings apart from men in marriage, if realised, especially in the context plagued by gender-based violence that South Africa has become, it could also be fatal.

It is noteworthy that in languages that emerge from oral cultures like the cultures of Africa, there are some words that, although difficult to explain, especially to outsiders to the languages, would make a lot of sense to an informed mother-tongue speaker. For example, the mention of the word kgarebe in the Northern Sotho context would entail the following amongst others: go tšwa komeng [initiation], go opelelwa [to have women sing for kgarebe and virginity issues] and go ba kgope [the state of being marriageable]. It occasions no surprise then, that one would hardly find sources that explain the meaning of the phrase, kgarebe yeo $e$ sa tsebego monna. The phrase is known exactly as it stands and it cannot be reversed to conform to what may be deemed 'normative' as in the following phrase: lesogana leo le sa tsebego kgarebe [translated, 'a grown up boy who does not know a virgin']. On the other hand, in the JudeoChristian tradition, especially in the Hebrew Bible, it is almost always a man who knows a woman sexually. In order to delimit the scope of our investigation, the text of Genesis 19:30-38 will be used to engage the topic interrogated in this study. What caught my attention as I read the preceding episode through the lens of kgarebe yeo e sa tsebego monna is the apparent female agency entailed in both the expression and the episode. The subject of the act of knowing (read: carnal knowledge) strangely in a patriarchal context is not a grown-up boy (lesogana). No. It is always kgarebe, who has not yet known a man. As I will show in the following section, when I turn to the Hebrew Bible though, I find a different reality. Which reality is it? We now turn to the preceding question.

\section{Daughters, agency and (carnal) knowledge (?): Lot's daughters in Genesis 19:30-38}

When I read the narrative on the daughters of Lot in Genesis 19:30-38 informed by facts outlined in the preceding section on kgarebe ye e sa tsebego monna, I was basically confronted by the direct opposite. Why so? The Hebrew word ידעי 'yada', which ordinarily means 'to

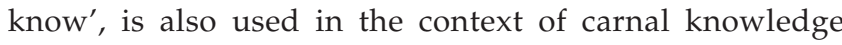
such as in the following usage:

Now the man knew his wife Eve, and she conceived and bore Cain, saying, 'I have produced a man with the help of the LORD'. (Gn 4:1, NRSV)

The girl was very fair to look upon, a virgin, who no man had known. She went down to the spring, filled her jar, and came up. (Gn 24:16, NRSV)

In the Hebrew Bible, a male, who is almost always a married man, either goes into, knows or lays with his wife. Thus, in the preceding cases, unlike in the African-South African context, a man is the subject who acts upon a woman. The object of a man's carnal knowledge is almost always a woman. A woman's body was viewed as carrying something of a mystery. Is it any wonder then that the sage could express this mystery when he wrote?

Three things are beyond me; four I do not understand (know): the way of an eagle in the sky, the way of a snake on a rock, the way of a ship in the heart of the sea and the way of a man in a woman. (Pr 30:18-19, [author's own italics]) 
Noteworthy although is the fact that in exceptional cases, men who were 'Othered', such as, aliens, slaves and intruders, amongst others, could become the objects of carnal knowledge by fellow men (cf. Gn 19:1-9). The male mob which features in the preceding episode demanded that Lot's male visitors be brought out that they may ידע [know] them sexually. In such cases, the perpetrators would have wanted to prove the normativity of their hegemonic masculinities over those of the ones who are made to occupy a feminine role (read: being known sexually). Such incidences which displayed the different layers of power within patriarchal hierarchies were, however, a deviation from the norm. As already noted, the norm appears to have been as follows: it is the female body which must almost always be the object not only of a male gaze but also of being known sexually by a male. Why? In his book, Knowledge, control and sex: studies in biblical thought, culture and worldview, Malul (2002:261) connects the answer to the question with the Hebrew word ידע (yada), which simply means 'to know'. The word also has reference to sexual intercourse or carnal knowledge, which is 'to know' in a tactile bodily sense. The mysterious and unknown insides of a female person necessitates that she be placed in the position of being the object of the act of knowing (Malul 2002:261). ${ }^{3}$

How may carnal knowledge then be defined? As against cognitive knowledge, carnal knowledge is tangible, bodily knowledge. We are our bodies; therefore we all experience our world bodily or carnally. As sex organs are part and parcel of the human sensory apparatus, we acquire knowledge also by means of sexual intercourse. Human beings experience the world as much as by their sex organs as by their ears, eyes and noses. It is the man, however, who always does the knowing with regard to the woman (he is grasping and controlling) and it is the woman who is always the object of knowing (she is receiving) (Malul 2002; cf Klopper 2012:89).

The story of Lot and his daughters in Genesis 19 is situated within the corpus generally known as patriarchal history (cf Gn 12-50). The key patriarchs who are foregrounded within the history of the interpretation of the book of Genesis are Abraham, Isaac and Jacob. As one can expect within patriarchal history, although the patriarchs' wives (cf. the matriarchs Sarah, not Hagar; Rebecca, Rachel, not Leah) enable the perpetuation of the lineage of the patriarchs by using their reproductive capabilities (usually not without a struggle due to their barrenness) effectively, they are basically invisible and silent. As can also be expected, they basically bear sons and not daughters. The following example can be cited as a case in point: in her efforts to win the favour of Jacob, a husband whom she shared with her sister Rachel by default (?), Matriarch Leah (and her maidservant), bore nine sons and only one daughter for Jacob! So, in the patriarchal narratives, the key role players, that is, persons with a sense of agency, are not women but men. In the preceding scheme

3. In such a context the unknown (read: female body) was tantamount to chaos, disorder and confusion (see Malul 2002 89). Thus, continues Malul, the picture of disorder and confusion (see Malul 2002:89). Thus, continues Malul, the picture of the other side of knowledge (ignorance) is that of some mysterious realm, shrouded by darkness, unfathomable, disorderly and chaotic. It is also shrouded by fright and even sheer terror (cf. Malul 2002:267). of things, the females are not passive though, they have a proper place, that is, that of being kgarebe ye e sa hlwago $e$ tseba monna (a grown-up girl who does not yet know a man (read: virgin) in the house of her father or a woman who should not know that her sexuality is contained and controlled by men (read: a wife in a heterosexual marriage). The words of Niditch (2012) come to mind here:

It is logical to assume that men - male priests and a lengthy scribal tradition - are responsible for incorporating into law and custom notions of what the 'proper' place of women is, namely, to be a young virgin in the father's home or a child-producing, sexually faithful wife in her husband's. (p. 33)

It should also be noted that key daughters who feature in the patriarchal history, that is Hagar and Dinah, are featured as objects for use (in matters of carnal knowledge) by those in power. Daughter Hagar, for example, is used as a surrogate by a powerful female in the person of Sarai. Sarai was also pressured by the customs of the time to provide her husband with another woman to bear children for her husband. The apparent agency of Sarai in the preceding case was thus not voluntary. It was dictated to her by the system of patriarchy. In the case of Daughter Dinah, as although biblical daughters were expected to be stuck in their fathers' houses permanently, her initiative to go out and meet her friends, 'daughters of the land' (Gn 34:1), meets with horror. Why so? She got exposed to a male gaze and lust and her virginity, the treasure ${ }^{4}$ that would open doors for a smooth transition into a heterosexual marriage, ended up being violated by Shechem, the Hivite, the prince of the land (Gn 34:3).

If one were to situate the contents of the narrative of Lot's daughters in Genesis 19:30-38 within the preceding short matriarchal herstory, one would thus be struck by what appears to be a reversal of the patriarchal status quo, a different reality. ${ }^{5}$ Points of dissonance thus outweigh points of resemblances. In Genesis 19:30-38, suddenly, daughters and not men or sons feature. As Fewell and Gunn (1993:62) rightly observed, 'Here Lot's daughters take charge of the story, assume a measure of subjectivity, if only briefly'. Lot's daughters take control of their sexuality. The man is present but according to patriarchal norms and values, he may be deemed absent. A male, an elderly one at that, is acted upon, not by other men, but by younger females, these invisible others both in the Hebrew Bible and many an African context.

Although the narrator makes the older daughter to mouth the words of ignorance about there being no man on earth to know the daughters sexually (Gn 19:31), it is doubtful that the firstborn indeed meant that there was no man in Zoar, the little town that her father Lot initially requested the angels to

4.Russaw (2018) reminds us that in the Ancient Near East, the daughter's virginity was an economic asset for her: 'For most non-royal daughters there was a positive correlation between virginity and bride price such that virgins commanded a higher bride price. It is in this way that virginity was an asset for a girl' (p. 7).
bring

5.In the view of Jackson (2002), Genesis 19 does not show the oppression of women in ancient Israel, it presents an alternative reality. She argues, '(in that reality) patriarchy was not the status quo, men were seen as fools for behaving as if they patriarchy was not the status quo, men were seen as fools for behaving as if they
were in control, and women were valued for motherhood and also for their intelligence, courage, inventiveness, creativity' (p. 46). See also Scholz (2013). 
let them flee to. Such gaps in the story has led scholars like J. Cheryl Exum and others to argue that the story is not about the daughters, but about Lot's fantasies, which are then projected onto the daughters. In the preceding line of argument, the main actors in this story are not the daughters but their father. Such an argument may not be that far-fetched as ordinarily, incest is not done by daughters on the father, but the father is almost always, the perpetrator. To such commentators we may ask: Does it not happen that in our attempts to 'redeem' the marginalised voices in the biblical text, we may be so blind-folded by our convictions of the pervasive androcentricism in the texts that we may even miss those texts with an emancipatory potential? In our attempt to challenge patriarchy at all costs, may we not end up further muting the marginal voices in the narratives? The preceding questions are raised because the grain of the text of Genesis 19:30-38 as it now stands allows us to see the daughters as active role players. Unlike Hagar and Dinah, who are acted upon by men, Lot's daughters in Genesis 19:30-38 are the key actors. And so argues Russaw (2018): 'They demonstrate their power and their autonomy as they exercise control over their bodies and the body of their father when they initiate sexual intercourse' (p. 74).

Although the daughters' main motive seems to be motivated by patriarchal norms and expectations, that of bearing sons for a specific lineage, Lot's daughters, like Tamar, decided on who the bearer of the sons should be. Russaw (2018:74) thus has a point: 'In Gen 19:32, the firstborn daughter is interested in maintaining her family line when she states: "so that we may preserve offspring through our father"'. It thus makes sense that the availability of other men, whether in the whole earth or in Zoar, has little to do with the decision of the daughters. Why? In that context, it was not a matter of offspring in general, but with a kinsman. The words of Wilson (2019), albeit in the traditional patriarchal sense, come to mind: 'The goal of male sexual virility in the HB is to produce legitimate heirs (ideal Israelites) by wives and not to heedlessly father many children by multiple random women ...' (pp. 39-40).

What should also be noted with Fewell and Gunn (1993:63), and understandably so, is the patriarchal orientation of the language used by the daughters. Lot's daughters seem not to be so much concerned to have children. We may also add that their concern was not so much to have sex with a man. The question of carnal knowledge appears to be basically used as a means to an end. Possibly, not even in their wildest dreams would Lot's daughters have thought that they would have ended up being powerful matriarchal figures of particular nations, that is, the Moabites and the Ammonites. Lot's daughters are concerned 'to make seed live' (Fewell \& Gunn 1993:63).

When the system failed the daughters by not enabling them to transition from the father's household into the household of their husbands in order to mother children (read: sons) through their husbands, they take initiative and do it in their own terms. Could it be a matter of the proverbial sore that itches to its owner? Russaw (2018:13) argues, 'By usurping the male role and controlling their own sexuality, Lot's daughters are presented as models of resistance'. Although the narrator overtly presents an episode of a reversal of the patriarchal status quo in which daughters take control of the situation and initiate as well as become active on the issue of carnal knowledge, the conventional word 'yada' [know] is never used to describe what they do; instead, the basic terminology used albeit with different prepositions is šakab [to lie with]. According to Holladay (1971), šakab can be used with 'im (Gn 19:32); it can also be used with 'et (Gn 19:33). The use of the different words used with šakab does not affect the idea conveyed by the phrase, which means, 'to lie with' in the context of carnal knowledge. ${ }^{6}$ Instead, the narrator uses the word yada to describe Lot's lack of cognitive knowledge of what happened to him. Perhaps, the narrator decided to keep intact the integrity of the male in question. We may conclude that unlike in the case of the Northern Sotho kgarebe who can know a man, in this episode, a female can never 'know' a man.

Although the vocabulary of carnal knowledge with females as subjects appears evasive to the narrator, the daughters' strategy and sense of urgency may persuade the reader to agree with the words uttered by their father to the mob at the beginning of the chapter, that is, Lot's possession of 'daughters who have not known a man' (Gn 19:8). In the present pericope, the daughters are the ones who know the man, dikgarebe tša go tseba monna.

\section{Conclusion}

As we draw the discussion to a conclusion, we may want to ask if the phrase kgarebe ye e sa hlwago e tseba monna is really empowering to the daughters of Africa or not. The answer to the preceding question can be in the affirmative: Firstly, inherent in the preceding phrase is the fact that kgarebe can be a subject in her own right, especially on matters of carnal knowledge. The female subject can choose whether she will ever know a man sexually or not. If her choice leans towards marriage for example, she can choose at what point she can decide to know a man sexually. The toxic concept of child marriage can thus never be part of the preceding equation or package.

The phrase kgarebe ye e sa hlwago e tseba monna thus also entails the capacity of this female other, to have control over her sexuality. The latter entails that there should be resistance to death-dealing cultural practices such as female genital mutilation, virginity testing and any death-dealing religious, cultural and economic ventures performed on the female body. The preceding points speak to the grown up girl's capacity to be agentic and resistant, her capacity to heed Vellem's call: 'VukaniBantuTsohangBatho'. She is called upon to arise $(\operatorname{tsog} a)$ and be an agent of positive change for the transformation of those on the margins of $6 . F o r$ a detailed response on the preceding discussion, see Orlinsky (1944). 
our communities. As the one who receives the short end of the stick in our patriarchal contexts, kgarebe is called upon to resist gender-based violence and sex-trafficking, to resist the temptation from the lures of neoliberal capitalism by prematurely 'knowing sexually' older men in the form of sugar daddies and male blessers.

On the negative side, even more than 20 years into a democracy, even with a possession of one of the most affirming constitutions in the world in terms of human rights, South Africa remains a country that is very unsafe for its female members: gender-based violence, rape (including marital rape) and femicide amongst others, have become the order of the day. In such contexts, the integrity of the female body and the sanctity of female life are trampled upon with impunity. The institution of magadi [lobola], which has lost its traditional meaning with its commercialisation of female persons, helps to sustain the continued control of female sexuality by men within marriage contexts. Whilst the sexuality of married women is contained and controlled, the opposite holds for their male counterparts. Their bodies can, also sanctioned by sacred sayings (read: proverbs), ${ }^{7}$ be shared with other women!

What about Lot's daughters? Like kgarebe ya go se tsebe monna, they take charge of their lives, and in particular, the control of their own bodies and sexuality. Although the narrator is possibly influenced by patriarchal norms and values to deliberately choose to use a less loaded word such as שכב (šakab) 'to lie with' instead of the regular ידע yada [to know sexually], to connote carnal knowledge in the context of Genesis 19:30-38, the readers know that the initiative and agency do not come from a male, but from younger females. The reader has already gotten a glimpse about the daughters who are agents in Genesis 19:30-38. They are, according to Lot, '... two daughters who have not known a man' (Gn 19:8).

The actions of the daughters of Lot remind us that subordinated persons (be they the objects of Western imperialism, post-apartheid racism and classism, neoliberal capitalism, patriarchy, pandemics such as HIV and AIDS and COVID-19 with their Black feminine face, and androcentric death-dealing interpretations of sacred texts, be they from the JudeoChristian traditions or African oral texts) have a sense of agency. In their own unique way, they can use whatever means available (sometimes at all costs) to bring hope to a situation without one. Hence, Fewell and Gunn (1993) can argue:

While YHWH rains down brimstone and fire, overturns cities and wipes out whole populations, the most vulnerable and subordinated characters in the story take charge of their own lives, as they have been led to understand them, by doing what must be done to bring seed to life. (p. 63)

The episode also reminds us that in androcentric texts in which female voices are usually marginalised or muted, subordinated characters do have moments, albeit very few, to resist such systems of oppression either overtly or covertly. In that way, if read between the lines, readers can 'hear' voices of resistance from the marginalised Other. In the process, the marginalised Other may remind readers of biblical texts, that they have the capacity to take charge of their own sexuality. If a reader cares to listen to the voices, perhaps he or she may discover that those long-held cherished stereotypes about notions of femininity and masculinity were skewed. One such stereotype is that the female body is almost always the object of carnal knowledge by a male, hence the numerous proverbial sayings that endorse male virility and control. Could a close bosadi reading of the text of Genesis 19:30-38 turn some of the sayings upside down so that they could tell a fuller story as in the following examples?

Monna ke tšhwene o ja ka matsogo a mabedi ['a man is a baboon he eats with two hands'] becomes Monna ke tšhwene, o ja ka matsogo a mabedi ge go kgahla basadi ['a man is a baboon; he eats with two hands only when women have decided']. Monna ke phoka o wa bošego [a man is a fog he falls in the night] becomes monna ke phoka, o wela mo go ratago basadi ['a man is a fog he falls within the territory designated by women'].

As all batho (human beings), like the Honoree, the late Professor Vuyani Vellem, arise and strive for the transformation of our contexts, a fuller story may probably enable all of us to respect the human dignity embedded in all humans irrespective of their gender. As we do the latter, we may probably resist and challenge the stereotypes that make us to value other human beings more than others. We may consequently be able to affirm the full dignity of all human bodies, including the bodies of our daughters.

\section{Acknowledgements Competing interests}

The author has declared that no competing interest exists.

\section{Author's contribution}

I declare that I am the sole author of this research article.

\section{Ethical consideration}

This article followed all ethical standards for a research without direct contact with human or animal subjects.

\section{Funding information}

This research received no specific grant from any funding agency in the public, commercial or not-for-profit sectors.

\section{Data availability}

Data sharing is not applicable to this article as no new data were created or analysed in this study.

\section{Disclaimer}

The views and opinions expressed in this article are those of the author and do not necessarily reflect the official policy or position of any affiliated agency of the authors. 


\section{References}

Ackermann, D., Draper, J.A. \& Mashinini, E. (eds.), 1992, Women hold up half the sky: Women in the church in South Africa, Pietermaritzburg, Cluster.

Exum, J.C., 2000. 'Desire distorted and exhibited: Lot and his daughters in psychoanalysis, painting and film in essays in honor of Burke O. Long', Brown Judaic Studies 84, 83-108. https://doi.org/10.2307/j.ctvzgb93t.14

Fewell, D.N. \& Gunn, D.M., 1993, Gender, promise and power: The subject of the Bible's first story, Abingdon, Nashville, TN.

Holladay, W.L., 1971, A Concise Hebrew and Aramaic Lexicon of the Old Testament, E.J. Brill, Leiden.

Jackson, M., 2002, 'Lot's daughters and Tamar as tricksters and the patriarchal narratives as feminist theology', JSOT 26(4), 29-46. https://doi.org/10.1177/ 030908920202600402

Klopper, F., 2012, 'Those remarkable Israelite women', in E. Scheffler \& M. Masenya (Ngwan'a Mphahlele) (eds.), Biblical studies, The Bible and sexuality, study guide 1 for OTS3704, pp. 83-93, University of South Africa, Pretoria.

Kobo, F.A., 2019, 'A womanist dialogue with Black Theology of liberation in the twenty first century', PhD dissertation, University of Pretoria, Pretoria.

Malul, M., 2002, Knowledge, control and sex: Studies in biblical thought, culture and worldview, Archaeological Center Publication, Tel Aviv.

Masenya (ngwana' Mphahlele), M., 2004, How worthy is the woman of worth? Rereading Proverbs 31:10-31 in African-South Africa, Peter Lang, New York, NY.

Mofokeng, T., 1986, 'The evaluation of the Black struggle and the role of Black Theology', in I.J. Mosala \& B. Thagale (eds.), The unquestionable right to be free: Black Theology from South Africa, pp. 113-128, Braamfontein, Skotaville.
Mojapelo, M.L., 2020, Personal Conversation, 04 February.

Mosala, B.I., 1986, 'Black Theology and the struggle of women in South Africa' in I.J. Mosala \& B. Thagale (eds.), The unquestionable right to be free: Black theology from South Africa, pp. 129-133, Skotaville, Braamfontein.

Mosala I.J and Thagale B (eds), 1986. The unquestionable right to be free: Black theology from South Africa, Skotaville, Braamfontein.

Mosala, I.J., 1988, 'Implications of the text of Esther for African women's struggle for liberation in South Africa', Journal of Black Theology in Southern Africa 2, 3-9.

Niditch, S, 2012, 'Genesis', in C.A. Newsom, S.H. Ringe \& J.E. Lapsley (eds.), Women's Bible Commentary: Twentieth anniversary edition, revised and updated, pp. 7-50, Westminster John Knox, Louisville, KY.

Oduyoye, M.A., 1994, 'Feminist theology in perspective', in R. Gibellini (ed.), Paths in African theology, pp. 166-181, Maryknoll, Orbis.

Orlinsky, H.M., 1944, 'The Hebrew root SKB', Journal of Biblical literature 63(1944), 19-44. https://doi.org/10.2307/3262505

Ramodibe, D., 1989, 'Women and men building together the church in South Africa' in V. Fabella \& M.A. Oduyoye (eds.), With passion and compassion: Third world women doing theology, pp. 14-21, Maryknoll, Orbis.

Russaw, K.D., 2018, Daughters in the Hebrew Bible, Fortress Academic, London.

Scholz, S., 2013, Feminist interpretation of the Hebrew Bible in retrospect, Vol 1 : Biblical books, Sheffield Phoenix, Sheffield.

William, J., 1990, 'Towards a womanist theology of liberation in South Africa: Black domestic workers: A case study', Journal of Black Theology in South Africa 4, 24-35.

Wilson, S.M., 2019, 'Biblical masculinities studies and multiple masculinities theory: Past, present and future', in O. Creangă (ed.), Hebrew masculinities anew, p. 1940, Phoenix Press, Sheffield. 